\section{Japanese genomics combines state and industry backing}

Tokyo. Japan's genomics research received a major boost last week with the formal release of details of two new government -industry joint venture companies, the Helix Institute and Genox Research Institute Inc. (see Nature 378, 2; 1995).

Both will pursue the development and application of human genomic information. The Helix Institute will employ between 40 and 50 researchers and support staff, and will receive $¥ 6.6$ billion (US\$60 million) over its planned six-year lifetime, about three-quarters from government and the rest from 10 private companies.

The new company's president is Teruhisa Noguchi, vice-president of Yamanouchi Pharmaceutical. Its director of research is Yukio Takigawa of Mitsubishi Chemical. According to Yoshiro Ohtaki of Japan Associated Finance Corporation - a venture capital fund participating in the project - Takigawa was chosen for his experience as head of planning at another government-industry 'bio-venture', the Protein Engineering Research Institute in Osaka.

The new institute's laboratories are to be located at the Kazusa DNA Institute, a molecular genetics research centre set up by the Chiba prefectural government in Sarazu, east of Tokyo.

Ohtaki says that staff for the new institute will be recruited from the contributing companies and from the academic community, both in Japan and overseas. Three expatriate Japanese researchers from the US biotechnology company DNX have already been recruited. The research aims include development of methods for identifying functional genes, high-efficiency cloning technology and cellular systems for expressing functional proteins.

Genox Research Institute Inc., which will mainly pursue medical applications of genomic information, has been established with support from a venture capital fund operated by the Ministry of Health and Welfare (MHW) and from eight private companies. The institute will receive $¥ 4$ billion over its seven-year lifetime, half of which will come from the government.

Genox, which will be based at the National Centre for Children's Disease in Tokyo, plans to develop a system for crossreferencing genetic and clinical information, paying special attention to allergy. The institute's president, Haruo Naito, and head of research, Masaji Ono, are both executives of Eisai Pharmaceutical, one of the participating companies. Seven staff will be employed initially, but this may eventually increase to 20 . Stephen Barker

\title{
Researchers rally to save primate pioneer's station
}

Giessen \& London. A group of scientists and historians are stepping up an international effort to save the 80-year-old remains on Tenerife, in the Canary Islands, of one of the world's first research stations on primate behaviour, now in danger of being demolished to make way for a luxury housing complex.

More than 300 academics, including the directors of major primate research stations in Russia, Japan and the United States, have Near extinction? Houses could replace ape station. written letters and signed petitions urging the island authorities to preserve the anthropoid station, which made a name for its director, Wolfgang Köhler. His book The Mentality of Apes, one of his two major works that originated at the station, is considered a seminal contribution on chimpanzee intelligence.

"Köhler was one of the founders of the school of Gestalt psychology, and in effect a grandparent of cognitive psychology, its successor," says Robert Glaser of the University of Giessen in Germany who is coordinating the campaign to preserve the station.

Supporters of the campaign include Jane Goodall, scientific director of the Jane Goodall Institute in Hampshire, England, who says the building should be preserved as a museum. "Köhler contributed greatly to our understanding of our closest living relatives," wrote Goodall in a letter endorsing the petition. "His psychological tests still stand as examples of careful research that took account of the nature of the chimpanzee subjects," she says. "When I went into the field in 1960, The Mentality of Apes was my bible."

The station was established and sponsored by the Royal Prussian Academy of Sciences in 1913, and is located in the tourist resort of Puerto de la Cruz. It gave Köhler both the time and the space to observe reasoning in ten young chimpanzees that

\author{
IMAGE \\ UNAVAILABLE \\ FOR COPYRIGHT \\ REASONS
}

had been brought from west Africa.

\section{India signs up to CERN's new accelerator}

New Delhi. India has agreed to make a contribution estimated to be worth $\$ 25$ million towards the construction of the $7-\mathrm{TeV}$ Large Hadron Collider (LHC) planned for the European Laboratory for Particle Physics (CERN) in Geneva.

According to the terms of an agreement signed in New Delhi last week by R. Chidambaram, the secretary for the Indian Department of Atomic Energy (DAE), and Christopher Llewellyn Smith, the director general of CERN, India will supply 12,000 superconducting sextupole corrector magnets that will be located along the path of
Known as La Costa because of its proximity to the coast, the research station contained a large experimental playground area, an ape house, a laboratory and Köhler's house, Casa Amarilla, where he lived with his wife, Thekla, and their young children. But the site now lies on land earmarked for development into luxury housing, despite being designated in 1994 as a site of historical interest by the island council of Tenerife, the Cabildo.

The station, in addition, has since been damaged twice. "The walls are crumbling, the house has no roof and is in danger of collapse," says Austin Baillon, a retired oil company executive and a spokesman for the Wolfgang Köhler Association. Baillon believes the damage could be the work of the owners of the land. "The roof was taken down in the hope that the building would collapse due to rain and not bulldozers," he claims.

The building's present owners, believed to be a company called Canary Property, have declined several requests for an interview. The land was owned from 1918 to 1994 by the Yeowards, a British family, once involved in merchant shipping, that has had a long association with Tenerife. Requests for interviews with family representatives were not answered. Ehsan Masood

the proton beam passing through the 27kilometre circumference tunnel.

Indian scientists will also develop and supply software to control the synchrotron that will accelerate the protons to be injected into the LHC. A spokesman for DAE said that Indian scientists are also interested in participating in the construction of the two LHC detectors. He said that scientists from the Tata Institute of Fundamental Research in Bombay, DAE's own installations, and many universities will be involved in the construction of the detectors.

K. S. Jayaraman 